\title{
The Economic and Social Life in Egypt during the Reign of Ayyubid Sultan Saladin (567 AH -1171 AD) -589 AH/1193AD) a Vision through the Journey (Rihlat) of Ibn Jubayr
}

\author{
Isa Mahmoud Alazzam ${ }^{1}$ \\ ${ }^{1}$ College of Arts and Sciences, Department of Humanities, Jordan University of Science and Technology, Jordan \\ Correspondence: Isa Mahm oud Alazzam, College of Arts and Scie nces, De partment of Hum anities, Jorda n \\ University of Science and Technology, Jordan. Tel: 962-777-763-705. E-mail: isa.alazzam@yahoo.com
}

Received: March 26, 2013 Accepted: April 26, 2013 Onlin e Published: December 10, 2013

doi:10.5539/ach.v6n1p64 URL: http://dx.doi.org/10.5539/ach.v6n1p64

\begin{abstract}
This research aims to study the description, life and biography of the Ayyubid sultan Saladin by Ibn Jubayr, and the ec onomic and s ocial co nditions of Egypt as wi thessed and described by the traveler I bn J ubayr an d the following results are concluded:

First: Ibn Jubayr praised the Ayyubid sultan Salad in and his good conduct and behavior with the subjects, his fairness, his patience and forbearance, modesty and his keen in interest in Jihad for the Sake of Allah. He called him the (Just Sultan).

Second: Ibn Jubayr talked a bout the keen interest of the sul tan in the economic matters of the s ubjects and especially in $r$ egard t o $t$ ax reform in the s tate whe re he dropped them co mpletely, an d w orked to promote security and order, and securing the trade routes, and also gave an accurate description of the international trade stations in Egypt between the east and the west and the markets in some of the cities.

Third: Ibn Jubayr described the keen interest of the Sultan in regard to the religious and scientific institutions in the society like schools, mosques, religious landmarks and hospitals through the establishment of some of those institutions, and creating the endowments connected to each one of them, in addition to securing steady salaries for those working and serv ing in those in stitutions, and spending on the scho lars, students and th e poor who came to those institutions.
\end{abstract}

Keywords: Ayyubid, Sultan, Saladin, Ibn Jubayr, social, economic, Egypt, trade

\section{Introduction}

Ibn Jubayr is the traveler Mohammad Bin Ahmad Al-Kanasi Al-Andalusi, born in Andalucía in the year 539 AH /1144 A D, and studied the and ac quired the knowledge related to the holy Koran, the Su nnah" Sa yings and teachings of prophet Muhammad" and Is lamic jurisprudence, and his fame in Islamic history came through his book "Tathkira Bil Al-Akhbar An Itifaqat Al-Asfar" known as the ( journey of Ibn Jubayr which came as the fruit of his journey that lasted for three years, which commenced in the month of Shawwal in the year $578 \mathrm{Ah} / 1182$ $\mathrm{AD}$, and concluded in the month of Muharram in the year $581 \mathrm{AH} / 1185 \mathrm{AD}$, and he died in the year $614 \mathrm{AH}$ /1217 AD. The $\mathrm{m}$ ain purpose of the journey $\mathrm{w}$ as the Hajj pilgrimage to the holy places, an d the pursuit of knowledge (I bn Jub ayr, 1981; Al-Dhahabi, 1985). and his journey inclu ded Eg ypt, Hej az, Bilad A 1-Sham "Modern day Syria, Lebanon, Jordan and Palestine" and some the Mediterranean islands, and he described with accurate details the conditions of those countries which he visited from all aspects, the buildings and structures the economic, the political, the military, the social, the scientific and the religious.

And he gave an accu rate description of the Ayyubid st ate $d$ uring th e r eign of the Ayyubid su ltan Salad in especially the social and economic conditions, and he praised the justice of the Sultan and his good governance, and his interest in Jihad for the sake of Allah and called him the just sultan, and talked about the keen interest of the sultan in regard to the matters and lives of the subjects especially in re gard to se curity and order, and his interest in the societal institutions the scientific, the religious, the social and the economic like schools, mosques, religious landmarks and hospitals, also in addition to the interest in trade and economic conditions .

This study focu ses on th $\mathrm{e}$ in terest of th e sultan in the $\mathrm{m}$ atters of $\mathrm{t}$ he sub jects as $\mathrm{d}$ escribed b y the 
contemporaneous traveler Ibn Jubayr, and his book of Rihla (journey) will be the main source of this research, with abun dant citatio ns from th e book, an $d$ also so me contemporaneous sou rces will b e u sed to clarify, and complete some of the aspects of this study.

\section{Study Problem}

Despite the numerous studies about the Ayyubid state, an d the just Sultan Saladin, there is no co mprehensive study about the policy of the Sultan regarding the Egyptian society, so this stu dy aims to address this issue. The problem of the stu dy aim s to id entify the g reat and memorable deeds of the Ayyubid su ltan Saladin, and the extent of his interest in the conditions of his subjects as described by a witness to the era, the Moroccan traveler Ibn J ubayr, the st udy is al so based on other co ntemporary so urces t o co ver s ome aspects of the st udy by answering the following questions:

1- What are the viewpoint and the assessment of the traveler Ibn Jubayr regarding the sultan Saladin, his line of conduct and his reign?

2- How the sultan to ok interest in the conditions of his subjects in Egypt in term s of bo th the econ omic and socials aspects?

3- What are the aspects of the interest of the Ayyubid sultan Saladin in the religious and scientific institutions of the Egyptian society?

\section{Objective of the Study}

Identifying and acquiring further knowledge about the economic and social conditions of Egypt during the reign of the Ayyubid sultan Saladin thro ugh the study of the bo ok of Ibn Jabayr,s travel (Rihla of Ibn Jubayr) who visited Egypt during this period, particularly since that there is no comprehensive study about this subject .

\section{Literature Review}

The Ayyubid sultan Saladin and his line of conduct, interest of the su ltan in regard to the economic and social conditions of the Egyptian society.

\subsection{The Ayyubid Sultan Saladin}

The Just su Itan Salah -Edd in(Saladin) Yourself Bin Ayoub Bin Sh adi w as born in Tikrit fort (a city lo cated between Baghdad and Mosul), in the year $532 \mathrm{AH} / 1137 \mathrm{AD}$, and his father was a governor there (Wali), then his father moved with his family and his brother Assad-Eddin Shirkuh to Mosul ,then he moved to Bilad Al-Sham, and assumed a po sition with the just king Nour-Eddin Mahmoud Bin Zenki, who depended on him and made him very close and gave him a special status( Ibn Shaddad,1994; Ibn Al-Athir, 1987)

The political ro le of Salad in has emer ged after th e Fatim id c aliph A 1-Adid Led in Ellah (556 -567 AH/1160-1171AD) sought the aid of Sultan Nour-Eddin Zenki in the year 564 Ah/1168 AD) to aid Egypt against the Frankish invasion, and the latter had responded to the aid request and appeal, so he assembled an army led by the prince Asad-Eddin Shirkuh, and Shirkuh ha d succeeded on c ontrolling Egypt in R abii, Al-Awal in the year (564 AH /1168 AD) by as suming the vizier post, but he died not too long after that on the sec ond of Jumada Al-Akhera of the same year after a public service of two months and five days, which prompted the caliph to ask Saladin to assu me the vizier post, and gave him the title of king who aids (Al-Malek Al-Nasser; Ibn Al-Athir, 1987).

And in Muharram in the year $567 \mathrm{Ah} / 1171 \mathrm{AD}$, Sultan put an end to the Fatimid Caliphate in Cairo, and wrote a letter to the Abbasid caliph Al-Mostadii, Bi Nour Ellah (566 -575 AH / 1170 AD -1179 AD) upon the orders of the Sul tan Nour -Eddin Zen ki he ass umed the go vernance of E gypt (Ibn Al-Athir, 1987), then hi s influence spread to Bilad Al-Sham after the death of his master Nour-Eddin Zenki.In the year 569 AH /1 173 AD then to Hejaz and Yemen, and he fought the Franks fe rociously, and his victories were crowned with the capt uring Jerusalem in Sh a,ban i $n$ t he year 583 Ah / 1187 AD and m any of th e cities in Bilad Al-Sham (Ibn Shaddad ,1994).

Saladin died after Salat Al-Fajr (the early morning prayer) in the morning of Wednesday the twenty seventh of Safar of the year 589 AH / 1193 AD (Ibn Wasel, 1980), and he was of fifty seven years of age.

The historical sources had abundantly mentioned the feats of Saladin and his good conduct and behavior, and he had a solid moral and religious convictions. He attended the prayers with fellow Muslims, and loved reading the holy Koran and prophet's Hadith and hearing them, and he treated the rites of religion with abundant respect and reverence (Ibn Shaddad, 1994; Abu Shamah, 1997).

And he was and "may the mercy of Allah" befall upon him a just, merciful, devout, compassionate, seldom angry, 
decent, smiling, patient and keeps the promises and was good to assoc iate and deal with (Ibn Shaddad, 1994), and was generous and gave the person asking for help more than expected, and received people calling for help with great understanding and compassion, and treats and receives guests with heartfelt welcome (Ibn Shaddad, 1994), and so nothing was left in his treasury when he died except one dinar and fifty seven dirhams, and left behind him no house or real estate, gardens or any other forms of property (Ibn Shaddad, 1994).

Ibn Jubayr praised the justice of Sultan Saladin, and his good manners and behavior with the subjects, and his outstanding patience by saying "the memorable deeds of this Sultan and his purposes in justice and his defense of the religion are hard to count and they are very numerous (Ibn Jubayr, 1981). he also had a great modesty so he did not feel superior to any of companions, and his council was attended by many of the poor and the Sufis, and prepares for them many ki nds of foods , and wa s tolerant t owards his com panions, an d as I bn Al-Athir recounted and in one sentence said "he was a rare m an among his soldiers, of many good deeds and noble acts, with great zeal in Jihad against the infields, and his conquests indicate and confirm that" (Ibn AL-Athir, 1987).

And while speaking about the policy of some Muslim rulers and their mistreatment of the subject in regard to imposing taxes, he praised the sultan Saladin by saying "except this just sultan Saladin ...if he had aides to do the right a nd as Allah $\mathrm{t}$ he almighty wa nted that $\mathrm{M}$ uslims meet and group with $\mathrm{t}$ his su ltan with $\mathrm{p}$ leasant appurtenance and good deeds and acts then those harsh would not have been imposed" (Ibn Jubayr, 1981), and his prestige among kings is great and he had the lasting impact ...this just king (Ibn Jubayr, 1981) . and says in another place "and we did not find in the lands of this man a bad matter except this story which is the imposition of Zakat (alms)on traders - which was the deeds of high level of ficials who ran a ffairs of state and that was illegal" (Ibn Jubayr, 1981) .

The sultan Saladin held a justice council on each Monday and Thursday in a public council, and attended by the senior jurists, judges and scholars, and opens his doors so anyone who can reach him whether old or young or an old woman or an old man (Ibn Shaddad, 1962), and at all times all complaints and grievances were heard, and finding solutions to the complaints that he receives, and in that Ibn Shaddad says: "he did not turn back anyone seeking a matter or in need of something.... and was compassionate in dealing with subjects, and maintaining the recitation of the holy Koran, and knowledgeable of the Koran and adhering to its precepts, and he always heard whoever asked for his aid, and dealt with his grievance and his story" (Ibn Shaddad, 1964)

\subsection{The Interest of the Ayyubid Sultan Saladin in Economic Conditions of Egypt}

The sultan had worked to $r$ eform the econ omic conditions in Eg ypt since he took con trol in the year $567 \mathrm{AH}$ /1171 AD, so he issued a circular on the third of Safar To abolish the whole excise taxes (taxes with no basis in Islam) in the land of Egypt in order to rejuvenate the economic life and the some of what was con tained in the circular the following: "and we ordered by publishing this circular to waive all typ es of excise tax es for all the people of Cairo and Egypt and all traders frequenting them, and up to the coast Al-Maqsam(Al-Maqas), and Al-Minyah whether goo ds are expo rted or imported, so the trader comes and tr avels and loans, and trad es on land, sea, and whether invisibly or otherwise and is free to do free trade, and is not asked about trade in regard to imports or exports, and is not hindered in doing that in a), and he abolished the excise taxes in Bilad Al-Sham in the year $579 \mathrm{AH} / 1183 \mathrm{AD}$, and in this way he had declared the free trade in Egypt and Bilad Al-Sham.

Ibn Jubayr had described the excise taxes in Egypt by saying "there were excise taxes in all the land of Egypt and on all of wh at is sold or bo ught whether small or large, and even on drinking water from the Nile and in addition to other things, and this just sultan had abolished this damned fad, and spread justice and security" (Ibn Jubayr, 1981).

Ibn Jubayr accounted that the excise taxes were not only imposed on the traders, but were also im posed on the pilgrims performing the hajj during the Fatimid ere, with the amount of seven and a half dinars for every pilgrim, and the city of Aithab was the collection center of excise taxes on pilgrims, which were sent later to the emir of Mecca, and he who fails to pay the tax was subject to harsh torture, and Ibn Jubayr had described that by saying: "The pilgrim went into hardships trying to borrow this tax and suffered a lot accordingly, regardless whether the person is able to pay to not that specified tax on pilgrims, it had to be paid (and the person) cannot pay the tax was subject to harsh torture in Aithab ....using harsh ways which were brutal ... and in Jeddah much more of that torture for the person who did not pay the illeg al tax in Aith ab" (Ibn Jubayr, 1981), an d the Su ltan Saladin abolished those excise taxes on pilgrims, and he compensated the emir of Mecca every year two thousand dinars, and two thousand irdeb of wheat (Abu Shama, 1985), and Ibn Jubayr praised the sultan for abolishing the excise taxes by saying: "and the believers by Allah and through this just sultan were relieved from this great malice and pain, and praise is due for the sultan from all who b elieve that the hajj is one of the five pillars of Islam, and where the praise and prayer calls for him shall reach all lands and areas" (Ibn Jubayr, 1981). 
Also Ibn Jubayr talked about the ex istence of Zak at tax on all trad ers and pilgrims who enter Egypt by sea or land, and he also talked about the abuse in its collection. and he described that when he arrived at Alexandria by saying: "on e of the first th ings th at we saw wh en we arrive d the i nspectors that ca me aboard t he ship ...to register all what it had carried, so all the Muslims were gathered, and their names, descriptions and the names of their countries were written, and everyone of them was if he had goods or money had to pay Zakat without any investigation of their status and condition, and most of them came to perform the hajj and only had their food for the way, they were asked to pay regardless if they were able to pay ...so the inspection went on for all reasons trivial and not trivial, and matter was a $\mathrm{m}$ ess, and their hands searched of what they might have, and made to swear what was found are the only things that they have, and during that a lot of the people's causes were gone due to $m$ ixing of ha nds , and great hu stle, then they were released with great hum iliation and dis grace" (Ibn Jubayr, 1981), an d Ibn J ubayr ad ds "a nd some of t he heinous things that we saw a sm all gro up of Zakat inspectors ,carrying in th eir hands long large needles, so they board the boats for very thorough inspection and they even insert those needles in food containers fearing that there are goods or money there" (Ibn Jubayr, 1981).

But Ibn Jubayr affirms that the Sultan Saladin did not know anything about those excise taxes, el se he would have abolished them and in that regard he says: "and it is a definite issue that the sultan Saladin does not know about the matter, and if he knew he would have stopped it as he did with abolishing and removing what was even of greater importance and he would have fought and opposed them, and opposing and fighting them is a duty due to their a buse and mistreatment" (Ibn J ubayr, 1981) a nd he says in that regard in another place that: "and it is unquestionable that if the great su ltan Saladin knew about that and knowing his justice and altruism, he would have removed and abolished that" (Ibn Jubayr, 1981).

And we note that that the Zakat taxes that were imposed on traders, foreigners and pilgrim that Ibn Jubayr had mentioned were not found in the sources contemporaneous of the Sultan Saladin, and we did account for that except that of the account of Jubayr, who affirmed that those taxes were the work of the officials of the state, and definitely not known to the Sultan whom most historians have praised, and because they are excise taxes.

On the ot her hand, E gypt had played a $n$ i mportant role in th e in ternational trad e dur ing the r eign of su ltan Saladin, because it was a cond uit for transit trade between the east a nd the west, and the main trade route from India and china to Aden, and through the red sea to A ithab and then transported by land to the city of Qos and then to Aswan then through the Nile to the city of Egypt (Al-Fustat) and from there through the Al-Hakimi (after the Fatim id Calip h Al-Hakim B i Amr Ell ah ) gulf and then to Alexandria and onward to Europe (Khosrow, 1983).

Ibn Jubayr gave an accurate description of the most important stations of international trade in Egypt particularly the cities of Aithab and Oos, and he describes the Aithab port by saying: "and it is on e of the bu siest ports because the ships of India a nd Yemen arrive and depart from there in a ddition to the outgoing and incoming ships that carry pilgrims" (Ibn Jubayr, 1981).

And he describes the city of Qo s by saying: "and this city has abundant markets with broad and wide facilities and with great number of people due to the great numbers of pilgrims, Yemeni and Indian traders and the traders of Abyssinia because it is the destination of all, a m eeting point of for all, a nd the congre gation point of Moroccan, Egyptian pilgrims and all relate $\mathrm{d}$ to them, and they spread in the Aithab desert and they meet there when to go to pilgrimage to Mecca and when they come back from Mecca" (Ibn Juba yr, 1981) then Ibn Jubayr describes the road between Qos and Aithab and the de gree of $i$ ts crowdedness wi th trade ca ravans "a nd we traveled in the desert where we stay when night falls, and the Aithab and Qos caravans moving and outgoing and incoming, and the desert is safe... and we walked in that road trying to count the incoming and outgoing caravans and we failed to do so, especially the Aithab caravans carrying the goods of India that arrive in Yemen and then from Yemen to Aithab, and the item that we saw is the loads of pepper, to the point that imagined that it is value is that of the soil due to its great abundance, and the strangest thing that we witnessed was great loads of pepper and cinnamon and other goods on the side of the road without any guards which was left like that due to the camel fatigue or other reasons, and left in its place well kept from harm despite the gre at numbers of passersby of great number people from many places" (Ibn Jubayr, 1981).

The people of Aith ab had a p rominent ro le in the trad e and pilgrim transport to the city of Jedd ah, and that through the transport of goods to the city of Qos, and also transporting the pilgrims by land to Jed dah and th at was reflected on its inhabitants where they became wealthy possessing a great amounts of money" and its people who have the boats and ships that bring a great source of income" (Ibn Jubayr, 1981).

But Ib $\mathrm{n}$ Jubayr ex pressed his dissatisfaction with the greed of the people of Ai thab and their love of money particularly in regard to tran sporting the pilgrims, and in that he says: "and the people of Aithab in regard to 
pilgrims act as tyran ts where they pack pilgrims on ships as if they are chicken in cages, with little care and not caring much about what the sea may bring, and they say we make the plates, and the pilgrims have the souls which translates into callousness in regard to the souls of the pilgrims, and this is a saying well known amongst them" (Ibn Jubayr, 1981).

Ibn Jubayr had described the ships used in the transport of pilgrims in the red sea by saying "and the ships that they dispatch in this pharaonic sea (the red sea) are not well made where no a single nail is used but sewed with combined threads made from the crust of coconut and they use to sew the boats and they use also the date tree branches, and after they finish the ship like and also using fat or the ricinus grease or the shark grease which the best .... and the purpose of painting the ship is soften its body due to many reefs in the sea (the coral reefs ), and materials were brought from India and Yemen, and also the coconut crust, and the strangest thing is that the sail is made from the leaves of the palm tree, and overall structure it is proportionate" (Ibn Jubayr, 1981).

Ibn Jubayr also described how the camels were loaded with goods and passengers "and travelled in this desert (Aithab) only on camels due the ability of camels to withstand the scarcity of water, and the best thing used on top of the camel is a especially designed carriages of large size(shaqadif) and the best kind of those carriages are the Yemeni kind, where the two part of the carriage are co nnected with strong quality ropes and places on the camel, which provides comfort in travel while carrying both goods and passengers" (Ibn Jubayr, 1981).

Also Ibn Jubayr talked about the active trade relations between the Franks and Muslims despite the severity of wars between the two sides ,and in that regard he says:"and one of the most strange things is that while the fire of sedition rages between the two groups the Muslims and Christians where the two groups may actually collide and fight, we found that the Muslim and Christian traders go unhindered, we saw that at that time which was the month of J umada Al-Awal (the y ear 579 AH / 1183 AD) when Sal adin marched with the Muslim sol diers to attack the Kerak fort .... and the sultan besieged the fort and the besiege was long, while the caravans from Egypt to Damascus and the Franks countries were flowing , and also the movement of Muslims from Damascus to acre was flowing with smoothness, and The Christian traders went unhindered , and the both parties pay taxes paid in their coun tries respectively to the other party, and ag reement prevailed in all con ditions, while the warriors on both sides were busy with their warfare and fighting, the people had prosperity , and the life is for the one who wins, an $d$ th is is th e st ory of the people of the co untries in th eir wars... and the subj ects who were no $t$ the warriors go on unhindered, and security is available in all conditions whether in peace or in war" (Ibn Jubayr, 1981).

The just su ltan had worked to secu re the trad e routes between E gypt and Bilad Al -Sham from the Frankis h danger, "so whenever he heard about a caravan that left Bilad Al-Sham towards Egypt, he did go out to protect it from the Franks by providing security on the road, so that caravan will be delivered" (Al-Maqrizi, 1956). and the keen interest that the just sultan took in securing the trade routes, and spreading security and order throughout his state, and the reform of the tax system had reflected positively on the traders and the conditions of the subjects, and in that regard Ibn Jubayr says: " an d the ju stice of this Sultan gave the people a great sense of security, so they also carry out their work even at night, and the darkness of the night does not make them fearful, and as a result of that we saw the conditions of the subjects in Egypt and Alexandria that attest to the prevailing security" (Ibn Jubayr, 1981), and he adds: "and the strange things is that people work and act at night as if it is a day time and that prevails in all of their co nditions" (Ibn Jubayr, 1981) and he mentions in another place, a nd the people of his country enjoy prosperity that needs no further description (Ibn Jubayr, 1981).

The Ayyubid su ltan Salad in also took great in terest and care of ag riculture in Egypt by er ecting bridges and aqueducts, cleaning the Ni le river from sediments especially th at the Nile is co nsidered as the vital artery of agriculture in Egypt, an $\mathrm{d}$ the $\mathrm{m}$ inimum needed for ag riculture s hould be $\mathrm{m}$ ore than si xteen Thiraa, using a measurement of $t$ he Nile a marble co lumn th at measures twen ty two Thiraa, (one Thiraa, equals $54.04 \mathrm{~cm}$ ) (Hinz, 1980), and if the Nile measure is less th an the minimum specified, the au thorities in th at year do not collect levies or capitation, and if the measure reached 17 Thiraa, then all agricultural lands are irrigated and the land produces sufficient crops of the soil for two years (Al-Baghdadi, 1983), and if the flooding reaches a lev el when water is at $\mathrm{n}$ ineteen Th iraa, then this is th e op timal co ndition for the year as Ibn Jubayr af firmed (Ibn Jubayr, 1981), and we infer from the measurement level of the Nile during the reign of Sultan Saladin, that Nile water level was between sixteen Thira, and eighteen Thira, and eighteen Osbaa, (Osbaa, in Egypt equals to 3.125 $\mathrm{cm}$ ), and sources did not mention that a damage to agricultural crop occurred due to an excess level of eighteen Thira, and that what Ibn Jubayr had affirmed.

Ibn Jub ayr also talk ed ab out the in terest that the su ltan too $\mathrm{k}$ in erectin $\mathrm{g}$ what was called Su ltanate bridg es (erected by the orders of the sultan ) west of the city of Egypt (Al-Fustat) to facilitate the movement of soldiers if 
the city of Alexandria was invaded by Franks during the tide of the Nile, an $\mathrm{d}$ in th at he says, and some o f the enduring feats of this Sultan with lasting impact and benefit for Muslims was the aqueducts that he built in the western side of Egypt, seven miles away, after a pavement that stretched from the Nile area towards Egypt as if it was a mountain stretched on land, where after six miles is connected with the before -mentioned aqueduct, and with forty large arcs, an d the aqueduct is co nnected to the desert that lead s ultimately to Alexandria, and those works are some examples of the firm resolution of kings in anticipation of an attack on the sea port of Alexandria when the Nile floods and the land is covered with the Nile water which prevents the soldiers from carrying out their duties when needed (Ibn Jubayr, 1981).

Perhaps the eco nomic measure und ertaken by su ltan Saladin prevented Egypt in to en tering in to an economic crisis due to the po litical change after the fall of the Fatimid caliphate, despite that Al-Maqrizi had talked about the fear an $\mathrm{d}$ ap prehension of th e traders and the population du e to th e political ch ange, where the prominent traders resorted t o m ove their m oney fr om Eg ypt "and th e distress sp read am ong the population of Eg ypt, because gold and silver left Egypt and did not return , and people talked about that continuously, and if someone said red Dinar as if so meone said so mething strange and valuable, and if the person possessed that dinar, then that person felt that heaven had come to him" (Al-Maqrizi ,1956), and despite all of that the prices of grains and foodstuffs had actually fallen due to the firm grip of the sultan on the totality of the state af fairs, and his good financial management, and wheat of the weight of three Irdeb was sold for one dinars (Irdeb in Egypt equals 69.9 kg) (Hinz, 1980, p. 58), and eight irdeb of barely were worth one dinar, and fourteen irdeb of beans were worth one dinar, and Sugar each Qintar ( equals 100 pounds) (Hinz, 1980 )was worth three dinars and at the end of the Fatimid era one irdeb of wheat was sold for five dinar and a webah of barley was sold for one dinar one webah (equals $12.68 \mathrm{~kg}$ ) (Ibn Maysar, 1981).

\subsection{The Interest of the Ayyubid Sultan Saladin in Social Institutions of Egypt}

Sultan Saladin foc used on e stablishing a nd building schools, m osques, an d rel igious b uildings ( Al-Maqrizi, 1998), to spread kno wledge of the Sunni sect, so he established in Cairo in the year $572 \mathrm{AH} / 1176 \mathrm{AD}$ th e Shafi'i school, and another Maliki school (Abu Shama, 1997), and another Shafi'i school near the grave of Imam Al-Shafi'i in Al-Qarafah (Abu Shama, 1997) and also another Maliki school in Alexandria.

The sultan also established the endowments for each school, mosque or religious building that was established to be used for the people serving in those places and those who reside there, and in that connection Ibn Jubayr says: "and some of the feats of this Sultan that i nstill pride are the sc hools and the special places (reserved for the scholars and ascetics and for the purpose of serving the people of medicine and also for worship, so many people from many distant countries come there and they find a place to stay and a teacher who teaches them what they want to learn, money to support him in all conditions" (Ibn Jubayr, 1981), and that in addition to the endowments with an amount of two thousand dinars each month to be used to spend on the mosques and schools (Ibn Jubayr, 1981).

The sultan appropriated st eady sal aries for the pe ople serving those mosques like Imams and other pers on in service in those places, so he arranged that some Imams were paid five dinars while others may have little more or less than that, and this is one of the numerous virtues of the sultan, and many other feats that the we ca nnot identify (Ibn Jubayr, 1981), and as an example he had appropriated for the Amr bin Al-Aas in the city of Egypt thirty dinars daily to be spent on in terests of the mosque and the salaries of people serv ing the mosques like imams and others serving in different areas (Ibn Jubayr, 1981).

And he spent on all who came to those mosques and schools like students, scholars, the religious people and the poor, and Ibn Jubayr mentioned in regard to the social initiations in Cairo : "and no mosque or religious places or sites for the scholars and the poor or a sc hool was le $\mathrm{ft}$ without the grace and virtue of $\mathrm{s}$ ultan being felt and encompasses all who cam e there and nee ded to reside and all expenses paid by the state through Bayt Al-mal (the Islamic house of money)" (Ibn Jubayr, 1981).

And he ap propriated am ounts of m oney to s pend on the rel igious landmarks of C airo: "a nd they are of fine structure built very well, and look like well preserved and with fine structures like amazing gardens, and every group that live there prese rve them, and looks awe some, and the money appropriated for the people who take care of those places is flowing and given monthly" (Ibn Jubayr, 1981).

The care and interest of Sultan was also far reaching and included the care of the foreigners, the pilgrims and the people in need of help, so he allocated for them in the city of Alexandria the baths and hospitals which were also known as $\mathrm{t}$ he (hospitals of the foreigners) to treat th e illn esses th at af flict th ose foreigners, and other staff to supply them with medicines and food, and he also assigned other staff to visit the patients who cannot come to the hospital, And "alert the physician to their conditions so that patients are treated" (Ibn Jubayr, 1981), also the 
sultan allowed those foreigners to appoint a ruler from amongst them who resolves their disputes: "and they have chosen a ruler where they discuss their e mergencies and problems in hi s presence, an $\mathrm{d} c$ onsequently they enjoyed well being and good health" (Ibn Jubayr, 1981).

And he allocated special faci lities for fo reigner, and Ahmad Bin Toloun acted lik e a residence for th em, and allocated appropriated monthly rations, in additions to two pieces of bread given to every one of them daily (Ibn Jubayr, 1981) .

The s pending on foreigners was car ried out through the "end owments that the $\mathrm{s}$ ultan ha $\mathrm{d}$ al located for that purpose and in add ition to that what he ap propriated fro $\mathrm{m}$ Zak at Al-Ayn", the alms paid upo $\mathrm{n}$ al $\mathrm{l} \mathrm{k}$ inds of property except liquid money (Ibn Jubayr, 1981), and consequently the foreigner as Ibn Jubayr affirms, was on the road of benevolence and guarded with dignity (Ibn Jubayr, 1981).

Therefore I bn Jubayr p raised the sul tan Sa ladin: "a nd the sultan who enacted those commendable laws and established those good deeds and laws which were absent for a long time is Salad in ... may Allah the almighty keep him in the right path of righteousness" (Ibn Jubayr, 1981).

The su ltan also $t$ ook in terest in th e $m$ atters of the su bjects, an $d$ he estab lished $m$ any ho spitals wi th am ple endowments, and he ordered the e stablishment of a hospital in Cairo in a section of a palace in C airo (Abu Shama, 1997 ), an d a nother hospital in the ci ty of Egypt (I bn Jub ayr, 198 1) and estab lished a hospital in Alexandria (Ibn Jubayr, 1981).

Ibn Jubayr described the hospital in Cairo and the work regime by saying: " a nd it is one of the distinguished palaces in term $\mathrm{s}$ of beauty and spaciousness ... and a $\mathrm{n}$ administrator was a ppointed who was a person of knowledge and supplied with cabinets for drugs and enabled him to use and make syrups of all kinds, and part of the palace was equipped with beds with full linings to be used by the patients, and the hospital administrator had also the staff that help ed to 1 ook af ter the patients ar ound th e clock, an d of fer the foods and drinks that are needed, and not too far from that ar ea is an a rea alloc ated for women, and between the two a reas the re was another area with spacious courtyard with separate compartments with Iron windows that were used as places for the m entally - ill to be locked, and th e staf f to look after th em an d to attend to their $n$ eeds, an d the su ltan followed up in all the times by investigation and inquiry, and stressed immensely that care should be in the in the highest if levels, and in Egypt there is another hospital with exactly the same design" (Ibn Jubayr, 1981).

\section{Results}

First: Ibn Jubayr praised the just Ayyubid sultan Saladin and his good demeanor and con duct with the subjects, and his fairness and justice, his patience, humility, and his interest in jihad for the sake of Allah, and he called him the just sultan, and his prestige among kings is high and great.

Second: Ibn Jubayr talked about the interest of the sultan in the economic interests of the subjects especially in regard to tax system reform where he abolished excise taxes totally on the subjects in Egypt and Bilad Al-Sham, and worked to sp read security and or der, and securing the trade routes, he also gave an accurate description of the stations of international trade in Egypt between the east and west, and the market of some of Bilad Al-Sham cities and the trade relations between Muslims and the Franks in Bilad Al-Sham.

Third: Ibn Jubayr described the interest of the Sultan in the religious and scientific institutions of the society like schools, $\mathrm{m}$ osques, places for sc holars a nd ascetics a nd hos pitals through $\mathrm{t}$ he esta blish of $\mathrm{s}$ ome of $\mathrm{t}$ hose institutions, and providing the sp ecial en dowments for each one of th em, in add ition to providing a stead y salaries for the individuals in ch arge of them, and spending on those to come to those institutions like scho lars, students and the poor.

\section{References}

Abu Sh ama, S. M. A . (1997). In E. Ibrahim (Ed.), Al-Rawdatayn Fi Akhbar Al-Dawlatayn (Part 4). Beiru t: Al-Risalah Establishment.

Al-Baghdadi, A. Y. M. (1983). In A. G. Damascus (Ed.), Al-Ifadah Wal I,tibar Fi Al-Umur Al-Mushahadah Wal Hawadith Al-Mo,ayana Bi Ard Misr. Dar Qoteibeh.

Al-Dhahabi, S. M. A. (1985). In A. H. Mohamamd (Ed.), Al-Ibar Fi Khabar Man Ghabar (Part 4). Beirut: Dar Al-Kutub Al-Elmiyah.

Al-Maqrizi, T. A. A. (1973). In J. Eddin (Ed.), Iti'az Al-Hunafaa, Bi Akhbar Al-A'imah Al-Fatimiyah Al-Hunafaa (Part 3). Cairo: The higher council for Islamic affairs.

Al-Maqrizi. (1998). Al-Mawa'dh Wa Al-itibar Bi Thikr Al-Khotat Wa Al-Athar knows as Al-Khotat. Beirut: Dar 
Al-Kutub Al-Elmiyah.

Al-Maqrizi. (1956). In M. Z. Mohamamd (Ed.), Al-Suluk Li Ma'refati Duwal Al-Moluk (Part 4). Cairo: lajn at Al-Ta' lif Wal Tarjama Wal Nasher press.

Hinz, W. (1980). Islamic Weights and Measures and their Equivalent in Metric System. Amman: University of Jordan publications.

Ibn Jubayr, M. A. A. (1981). Rihla "Journey" of Ibn Jubayr. Publications of Dar Wa Maktabat Al-Hilal. Beirut: Dar publications and library Crescent.

Ibn Mamati, A. A. M. (1943). In A. S. Atiyeh (Ed.), Kitab Qawanin Al-Dawawin. Egypt: The Royal agricultural society.

Ibn Maysar, T. M. A. (1981). In F. Ayman (Ed.), Al-Montaqa Min Akhbar Misr. Cairo: The French institute for Oriental Archeology.

Ibn Shaddad. (1994). In J. Eddin (Ed.), Al-Nawader Al-Soltaniyeh Wal-Mahasen Al-Youseffieh (2nd ed.). Cair.

Ibn Wasel, J. M. S. (1980). In J. E. Al-Shayyal (Ed.), Mufarrej Al-Koroub Fi Akhbar Bani Ayoub. Egypt.

Nasser, K. (1983). Safarnama. King Saud University.

\section{Copyrights}

Copyright for this article is retained by the author(s), with first publication rights granted to the journal.

This is an ope $\mathrm{n}$-access article distributed under the te rms and conditions of the $\mathrm{Cr}$ eative Commons Attribution license (http://creativecommons.org/licenses/by/3.0/). 